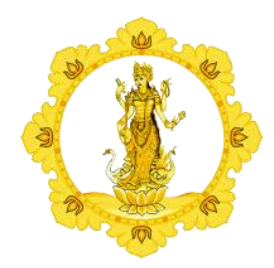

KALANGWAN

JURNAL PENDIDIKAN AGAMA, BAHASA DAN SASTRA

Vol. 11 No. 2 September 2021

\begin{tabular}{|l|l|l|}
\hline p-ISSN : 1979-634X & e-ISSN : 2686-0252 & http://ejournal.ihdn.ac.id/index.php/Kalangwan \\
\hline
\end{tabular}

\title{
SABDĀLAMKKARA DALAM KAKAWIN NĪTIŚĀSTRA: TAHAPAN DASAR KEPEMIMPINAN DALAM DIRI
}

\author{
Oleh : \\ Putu Eka Sura Adnyana \\ UHN I Gusti Bagus Sugriwa Denpasar \\ E-mail: ekasuraadnyana@ gmail.com
}

Diterima 29 Juli 2021, direvisi 21 Agustus 2021, diterbitkan 31 September 2021

\begin{abstract}
Abstrak
Kakawin adalah salah satu karya sastra Jawa Kuno yang mengandung nilai-nilai kehidupan sangat tinggi. Istilah kakawin berasal dari bahasa Sanskerta yaitu kawi dan dalam sastra Sanskerta klasik kawi berarti "penyair". Kakawin Nìtiśästra berasal dari kata Nìti dan śāstra. Nìti berarti undang-undang yang mengatur negeri sedangkan śāstra berarti pelajaran agama atau pelajaran dharma. Kakawin Nìtiśāstra dikarang oleh seorang pengarang yang tidak dikenali namanya, merupakan kakawin moralistis-didaktis. Teori yang digunakan adalah teori semiotika model Riffaterre. Metode yang digunakan dalam pengumpulan data dengan menggunakan metode simak yang dikombinasikan dengan teknik dasar catat. dilanjutkan dengan menggunakan metode dan teknik analisis data yang meliputi (1) Reduksi Data, (2) Penyajian data, dan (3) Verifikasi. Diakhiri dengan metode penyajian hasil analisis data menggunakan metode informal. Kakawin Nìtiśāstra hanya berisikan dan memuat anuprasa serta sabdālaṃkara yaitu puspayamaka dan wrêtantayamaka, namun didalam Kakawin Nìtiśástra tidak ditemukannya sabdālaṃkara yang lain seperti kanciyamaka, padādyantayamaka, padantayamaka. Kepemimpinan dalam teks Hindu seperti kakawin Nìtiśästra senantiasa berorientasi kepada tujuan hidup sekala dan niskala, jagatditha dan moksa yaitu, terpeliharanya keseimbangan hidup lahir dan batin.
\end{abstract}

\section{Kata Kunci : Sabdālaṃkara, Kakawin Nītiśāstra, Kepemimpinan}

\section{PENDAHULUAN}

Kakawin adalah salah satu karya sastra Jawa Kuno yang mengandung nilai-nilai kehidupan sangat tinggi. Istilah kakawin berasal dari bahasa Sanskerta yaitu kawi dan dalam 
sastra Sanskerta klasik kawi berarti "penyair". Kata kakawin diserap dalam bahasa Jawa Kuno yakni mengalami afiksasi dengan penambahan konfiks ka-ěn, selanjutnya vokal /i/ pada kawi sehingga terbentuk kata kakawin, berarti "karya seorang penyair, syairnya" (Zoetmulder, 1985: 119).

Pada perkembangannya Zoetmulder (1985: 480-507) menyatakan bahwa kakawin dapat digolongkan menjadi dua jenis yaitu kakawin mayor dan kakawin minor. Kakawin mayor berkembang sebelum masa pemerintahan Kerajaan Majapahit seperti Kakawin Ramāyana, Kakawin Bharatayuddha, Kakawin Krș̣nayana, Kakawin Arjunawiwaha, dan lain-lain. Kakawin minor adalah kakawin yang waktu penggubahannya lebih muda dari kakawin mayor dan biasanya merupakan turunan dari kakawin mayor, serta banyak digubah di Bali. Contoh kakawin minor misalnya Kakawin Subhadrawiwaha, Kakawin Hariwijaya, Kakawin Partawijaya, dan lain-lain.

Kakawin merupakan karya sastra yang subur ditanami nilai-nilai filosofis yang membuatnya bukan sekadar tumbuh sebagai sastra biasa, namun sebagai susastra (belles lettres). Kekayaan filosofis yang dimiliki oleh kakawin bukan sekadar kebetulan. Kakawin digubah oleh pujangga-pujangga melalui proses perenungan dan analisis yang sangat dalam. Tidak jarang para kawi "pengarang" kakawin terlebih dahulu akan bersentuhan pada alam melakukan perjalanan suci untuk mencari inspirasi penggubahan, sehingga menghasilkan karya yang merupakan hasil eksploitasi alam yang diterjemahkan oleh alam.

Salah satu kakawin yang digunakan sebagai objek pada pembahasan dalam karya ilmiah ini adalan Kakawin Nìtiśāstra. Anandakusuma (1986) menyatakan Kakawin Nītiśāstra berasal dari kata Nìti dan śāstra. Nìti berarti undang-undang yang mengatur negeri sedangkan śāstra berarti pelajaran agama atau pelajaran dharma. Kakawin Nìtiśāstra dikarang oleh seorang pengarang yang tidak dikenali namanya, merupakan kakawin moralistis-didaktis.

Di India kuno, kitab-kitab Nìtiśāstra. adalah kitab-kitab yang mengandung kebijaksanaan hidup dan pelajaran secara umum. Nama ini dengan kata lain adalah nama umum atau generik, Dalam bahasa Jawa kuno, pengertiannya juga sama. Jika seseorang membicarakan Nìtiśāstra. Ia belum tentu merujuk pada kakawin ini. Poerbatjaraka menunjukkan bahwa kakawin ini ternyata terjemahan daripada seloka-seloka dalam Bahasa Sansekerta. Menurut beliau, kakawin ini digubah pada abad ke 15 Masehi.

Sebagai suatu karya sastra, Kakawin Nìtiśāstra memiliki nilai estetika yang terlahir dari gaya bahasa yang digunakan dalam penggubahannya. Keindahan bahasa yang digunakan dalam kakawin lebih dikenal dengan istilah alamkara Kata Ala $\div$ kara berarti hiasan, dekorasi, hiasan-hiasan gaya, bahasa artistik, bahasa yang berbelit-belit atau terlalu dibuat-buat, sesuatu yang menakjubkan atau mempesona, bentuk yang fantastic (Zoetmulder,1985: 22). Dari artiarti tersebut, salah satu rangka kakawin yaitu Ala $\div$ kara yang merupakan bahasa artistik yang berfungsi untuk meningkatkan kualitas estetik kekawin.

Alamkara dapat berupa permainan bunyi yang disebut sabdālamkara dan berupa permainan arti kata yang disebut arthālamikara (Hooykaas,1958: 34), dalam karya tulisan ini hanya ditemukan sabdālamkkara dalam Kakawin Nìtiśästra, tulisan ini bertujuan untuk memahami permainan bunyi yang terjadi pada Kakawin Nìtiśāstra dan memberikan manfaat pengetahuan untuk masyarakat umum, terutamanya yang menyukai kesusastraan Jawa Kuno (kawi) khususnya kakawin.

\section{TEORI DAN METODE}

Memahami dan menelisik sabdālaṁkara dalam kakawin Nìtiśāstra memerlukan pemahaman akan sebuah teori. Teori yang digunakan adalah teori semiotika model Riffaterre mengemukakan metode pemaknaan yang khusus. Dikemukakan Riffaterre, untuk memberi makna karya sastra sebagai sistem tanda-tanda itu, istilahnya memproduksi makna tanda-tanda. Riffaterre, dalam bukunya Semiotics of Poetry (dalam Ratih, 2016), mengemukakan empat 
pokok yang harus diperhatikan untuk memproduksi arti (makna), yaitu (1) ketidaklangsungan ekspresi puisi, (2) pembacaan heuristik dan hermeneutik atau retroaktif, (3) matriks, model, varian-varian, dan (4) hipogram.

Metode yang digunakan dalam pengumpulan data dengan menggunakan metode simak yang dikombinasikan dengan teknik dasar catat. Metode simak ini dipilih karena objek yang diteliti berupa bahasa yang bersifat teks (Sudaryanto, 2015:205-206) yang terdapat pada sabdālamkkara dalam kakawin Nìtiśāstra, dilanjutkan dengan menggunakan metode dan teknik analisis data yang meliputi (1) Reduksi Data, (2) Penyajian data, dan (3) Verifikasi. Diakhiri dengan metode penyajian hasil analisis data menggunakan metode informal.

\subsection{Sabdàla $\div$ kara}

Sabdālamkkara adalah permainan bunyi yang terdapat pada suatu kakawin, dibedakan atas dua macam, yaitu (1) anuprasa, dan (2) yamaka. Adapun yang ditemukan sebagai berikut.

\subsubsection{Anuprasa}

Anuprasa adalah permainan bunyi, baik berupa asonansi (permainan vokal) maupun aliterasi (permainan bunyi konsonan). Permainan bunyi ini dilakukan dengan mengulang-ulang satu vokal atau konsonan secara teratur sehingga menimbulkan nilai artistik (Suarka, 2009: 30). Bentuk anuprasa dapat dijumpai dalam kutipan Kakawin Nītiśāstra berikut;

\section{Ring wwang tan wruha ring śubhäśita mapunggung mangraseng șadrasa, \\ Tan wruh pangrasaning sêdah pucanga doh tambüla widyāsêpi, \\ Yan wwanten mawiweka śästra nirapekșa byakta monabrata, \\ Yan wwang mangkana tulyaning rahinikā lwirnyan guwekā hidhêp.}

(Kakawin Nìtiśāstra, I.2)

Terjemahan:

Orang yang tidak hirau terhadap ucapan yang baik, tidak tahu merasakan enam rasa itu,

Tidak tahu akan rasa sirih pinang karena bodohnya meracik ilmu juga tiada tahu,

Bila ada orang membicarakan ilmu pengetahuan jelas akan acuh tak acuh serta diam seribu bahasa,

Orang semacam itu tak ada bedanya rupanya seperti gua bila diandaikan.

Pada kutipan bait kakawin Nìtiśāstra yang berwiramakan śarddhūlawikrīdhita di atas tampak bunyi r,g,s, w diulang-ulang dalam susunan kata. Bunyi $\mathbf{r}$ pada baris pertama diulang sebanyak 5 kali, pada baris kedua diulang sebanyak 2 kali, pada baris ketiga diulang sebanyak 3 kali, dan baris keempat diulang sebanyak 3 kali.

Bunyi g pada bait kakawin Nītiśāstra dalam baris pertama diulang sebanyak 8 kali, pada baris kedua bunyi $\mathbf{g}$ diulang sebanyak 3 kali, dalam baris ketiga bunyi $\mathbf{g}$ tidak diulang, namun pada baris keempat kembali diulang sebanyak 4 kali pengulangan.

Bunyi s pada bait kakawin Nītiśāstra diulang-ulang dalam baris pertama sebanyak 5 kali, pada baris kedua bunyi s diulang sebanyak 3 kali, dalam baris ketiga bunyi s diulang sebanyak 3 kali, namun dalam baris keempat bunyi s tidak ada pengulangan kembali.

Bunyi w pada bait kakawin Nìtiśāstra diulang-ulang dalam baris pertama sebanyak 3 kali, pada baris kedua diulang sebanyak 2 kali, dalam baris ketiga bunyi w diulang sebanyak 4 kali, dan pada baris keempat bunyi w diulang sebanyak 4 kali.

Pengulangan bunyi - bunyi tersebut dalam susunan kata yang diatur sedemikian rupa melalui repitisi sehingga bunyi - bunyi tersebut dapat menimbulkan daya estetik.

\subsubsection{Yamaka}

Yamaka adalah suatu permainan bunyi dalam bentuk yang lebih sistematis melalui permainan suku kata atau kata baik di awal maupun di akhir baris (Hooykaas,1958:40). 
Yamaka dapat dibedakan atas lima macam, yaitu (1) Kanciyamaka; (2) puspayamaka; (3) Padādyantayamaka; (4) padantayamaka; dan (5) Wrêntayamaka.

1) Kanciyamaka adalah permainan bunyi berupa pengulangan suku kata akhir baris sebelumnya diulang pada awal baris berikutnya. Contoh bait kakawin yang menggunakan permainan bunyi kanciyamaka tidak dapat ditemukan pada kakawin Nìtiśāstra.

2) Puspayamaka adalah permaianan bunyi berupa persamaan suku kata di akhir setiap baris dalam satu bait. Sebagai contoh dalam kakawin Nītiśāstra dapat dilihat sebagai berikut;

a) Kokila swaranya makarūpa kinalêwihakên

Strī makarūpa diwya kapatibrata linêwihakên

Ring śruti dharma śastra guru waktra kinalêwihakên

Ring kṣama rūpa sang parama paṇdhita linêwihakên.

Terjemahan:

(Kakawin Nìtiśāstra, II.6)

Burung gaga merah suaranya sebagai tanda yang betul-betul menjadi sanjungan,

Wanita yang dianggap cantik apabila mengutamakan kesetiaan terhadap pasangannya (suami),

Bila pada śruti serta dharmaúastra hanya ajaran gurulah yang patut diutamakan,

Rela dan ikhlas mengampuni itulah sebagai pertanda yang selalu diutamakan oleh seorang pendeta.

Pada kutipan di atas tampak setiap baris diakhiri dengan suku kata akên, namun ada yang unik dalam bait kakawin Nītiśāstra yang berwiramakan Wangśapatra patita, tepatnya pada baris pertama dan baris ketiga yaitu diakhiri dengan kata kinalêwihakên serta pada baris kedua dan baris keempat diakhiri dengan kata linêwihakên.Ini merupakan salah satu kecakapan pengarang Kakawin Nìtiśāstra dalam mengarang kakawin tersebut.

b) Śila pangawruheng kula sirang sujana panêngêran,

Ring warabhoga puștiningawaknya juga panêngêran,

Sihning amitra sambramatikā tiśaya panêngêran,

Ring ksama lenupekșa sira sang wiku panêngêran.

(Kakawin Nìtiśāstra, II.8)

Terjemahan:

Berdasarkan tingkah laku dapat diketahui asal usulnya seperti cirri seorang keturunan utama,

Jenis makanan yang baik yaitu yang dapat menjadikan badan sehat sebagai pertanda,

Erat bersahabat cukup banyak pemberian/hidangannya sebagai pertanda,

Ketenangan serta keikhlasan isi hati anda itulah suatu ciri anda seorang pendeta.

Pada kutipan bait Kakawin Nìtiśāstra yang berwiramakan Wangśapatra patita di atas tampak setiap baris diakhiri dengan kata panêngêran, sehingga hal ini dapat menimbulkan daya estetik dan keindahan yang diinginkan oleh pengarang (sang kawi).

3) Wrêntayamaka adalah permainan bunyi berupa persamaan suku kata di awal setiap baris dalam satu bait kakawin. Beberapa contoh bait kakawin Nìtiśāstra yang menggunakan permainan bunyi Wrêntayamaka dapat dilihat sebagai berikut; 
Norana mitra manglêwihane waraguna maruhur,

Norana śatru manglêwihane gêlêngana ri hati,

Norana sih manglêwihane sihikangatanaya,

Norana śakti daiwa juga śakti tanana manahên

(kakawin Nìtiśāstra, II.5)

Terjemahan:

Tidak ada sahabat yang akan melebihi dari ketrampilan dan pengetahuan yang tinggi

Tidak ada musuh yang akan melebihi dari kemarahan yang berada dalam hati

Tidak ada rasa sayang yang berlebihan selain rasa sayang terhadap anak

Tidak ada yang sakti hanya Sang Hyang Widhi yang sakti tak terbendung.

Setiap baris dalam permainan Wrêntayamaka diatas pada kakawin Nìtiśāstra yang berwiramakan Wangśapatra patita tampak dimulai dengan kata yang sama pada kata awal setiap baris dalam satu bait, yakni kata Norana. Namun disatu sisi juga ada hal yang menarik dan unik yaitu pada kata ketiga dalam baris pertama hingga baris ketiga yaitu adanya kata manglêwihane tetapi dalam baris keempat kata tersebut tidak ada dimunculkan, Hal ini tentu bertujuan untuk menentukan nilai keindahan dan estetika Kakawin Nītiśāstra tersebut.

Waśita nimittanta manêmu lakûmi,

Waśita nimittanta pati kapangguh,

Waśita nimittanta manêmu duhka,

Waśita nimittanta manêmu mitra.

(Kakawin Nìtiśāstra,V.3)

Terjemahan:

Karena perkataan menyebabkan bertemu kebahagiaan,

Karena perkataan menyebabkan datangnya kematian,

Karena perkataan menyebabkan bertemu kesengsaraan,

Karena perkataan menyebabkan bertemu sahabat.

Kata pada awal setiap baris dalam permainan Wrêntayamaka diatas dalam Kakawin Nìtiśāstra yang berwiramakan Kusumawicitra tampak dimulai dengan kata yang sama, pada kata awal setiap baris dalam satu bait, yakni kata Waśita dan nimittanta. Namun disatu sisi juga ada hal yang menarik dan unik yaitu pada kata ketiga dalam baris pertama, baris ketiga dan baris keempat yaitu adanya kata manêmu tetapi dalam baris kedua, kata tersebut tidak ada dimunculkan, Hal ini tentu bertujuan untuk menentukan nilai keindahan dan estetika Kakawin Nìtiśāstra yang diinginkan oleh sang pengawi.

Sāksāt dagdag gêsêng tikang wadana yan kita tananglinanga rikang sabhā, Säksāt dagdag gêsêng tikang muka yadin prihawaka nginange rikang sabhā, Sāksāt dagdag gêsêng wwanganwami wayahnya dumadaki kahìna kasyasih, Sāksāt dagdag gêsêng huwus jadha pikun dumadakanêmu bhāgya wiryyawān.

(Kakawin Nìtiśāstra,VIII.2)

Terjemahan:

Bagaikan terbakar wajah itu apabila anda tidak menikmati sesuatu dalam persidangan. Demikian pula seperti hangus wajah itu bila hanya seorang diri menikmati dalam persidangan,Seperti terbakar seseorang perjaka dikala tuanya apabila mendadak miskin serta menderita, Bagaikan terbakar hangus orang yang sudah jompo bila mendadak mendapatkan kebahagiaan serta martabat. 
Kata pada awal setiap baris dalam permainan Wrêntayamaka diatas dalam Kakawin Nìtiśāstra yang berwiramakan Kusumawicitra tampak dimulai dengan kata yang sama, pada kata awal setiap baris dalam satu bait, yakni kata $\boldsymbol{S a} \overline{\boldsymbol{k}} \boldsymbol{k} \boldsymbol{a} \boldsymbol{t}$, dagdag, dan $\boldsymbol{g} \hat{\boldsymbol{e}} \mathbf{s} \hat{\boldsymbol{e}} \boldsymbol{n g}$ Hal ini tentu bertujuan untuk menentukan nilai keindahan dan estetika Kakawin Nìtiśāstra yang diinginkan oleh sang pengawi.

4) Padādyantayamaka adalah permainan bunyi berupa perulangan kata pada awal setiap baris dalam satu bait kakawin, namun didalam Kakawin Nītiśāstra tidak dapat ditemukannya permainan bunyi padādyantayamaka.

5) Padantayamaka adalah permainan bunyi berupa pengulangan suku kata atau kata-kata di akhir baris dalam satu bait kakawin, namun dalam Kakawin Nìtiśāstra tidak ditemukan permainan bunyi padantayamaka.

\subsection{Tahapan Dasar Kepemimpinan Dalam Diri}

Mempelajari Niti Sastra bertujuan agar tercapainya tujuan Dharma, dalam pustaka Manava Dharmaśāstra, adhyaya VII.10 menjelaskan Karyam so veksya saktim ca Desakalau ca tattvatah, Kureta Dharma sidhyartham Visvarupam punah-punah yang bermakna setelah mempertimbangkan sepenuhnya maksud, kekuatan dan tempat serta waktu, untuk mencapai keadilan ia menjadikan dirinya menjadi bermacam wujudnya, untuk mencapai keadilan yang sempurna. Dalam mencapai kebenaran hendaknya harus mertimbangkan lima unsur yang disebut Iksa, Sakti, Desa, Kala dan tattwa.

1. Iksa disini berarti pandangan atau cita-cita untuk mencapai kesejahteraan.

2. Sakti disini berarti kekuatan atau kemampuan, dalam mencapai cita-cita hendaknya harus memiliki kekuatan yg sesuai.

3. Desa disini berarti batasan-batasan atau juga bisa disebut dengan keadaan. Dalam berbuat hendaknya harus mengetahui keadaan terlebih dahulu sebelum bertindak.

4. Kala disini berarti waktu, hendaknya juga harus mempertimbangkan waktu sebelum melakukan sesuatu.

5. Tattwa disini berarti hakekat kebenaran, dalam menjalankan sesuatu hendaknya berdasarkan atas kebenaran.

Kakawin Nitiśāstra hendaknya pahami dan terapkan dalam diri terlebih dahulu sehingga dapat memberikan contoh kepada orang lain. Ada tiga perbuatan dalam diri yang harus disucikan alau yang sering disebut dengan Tri Kaya Parisudha. Adapun bagian dari Tri Kaya Parisudha antara lain: Manacika Parisudha yakni berpikir yang baik, Wacika Parisudha yakni berkata yang baik, dan Kayika Parisudha yaitu berbuat yang baik. Ajaran Kakawin Nītiśāstra sudah memberikan contoh bagaimana hendaknya berpikir, berkata dan bertingkah laku atau berbuat yang baik dalam memimpin diri sendiri.

Selain itu, Kakawin Nìtiśāstra mengajarkan model pola asuh anak dalam tulisan ilmiah berjudul Citra dan Hak Anak ditulis oleh ditulis Suarka (2016) dijelaskan bahwa kakawin Nìtiśāstra menuntut orangtua untuk sangat memperhatikan hak anak, meliputi untuk tumbuh dan berkembang, hak untuk mendapatkan pendidikan, perhatian, kasih sayang, dan perlindungan dari berbagai tindakan kekerasan. Lebih lanjut Suarka (2016) menyebutkan pada saat usia anak 0 sampai lima tahun, orangtua patut memperlakukan anaknya sebagai pangeran yang disayang dan dimanjakan. Hal itu didasari pandangan bahwa anak yang berusia nol sampai lima tahun masih sangat belia. Pada usia 5-10 tahun, merupakan masa ideal bagi orangtua untuk memberikan pendidikan dan pelatihan kepada anak, terutama membaca, menulis, dan berhitung. Selanjutnya, saat anak remaja, orangtua memperlakukan anak sebagai 
sahabat karib. Pada usia enam balas tahun, anak sudah menuju kematangan fisik dan mental, serta mempunyai ketegangan antara identitas diri dengan tidak adanya dukungan dari sekitarnya. Setelah berusia 20 tahun, seorang anak sudah dianggap memiliki kematangan. Sehingga dalam teks Kakawin Nìtiśästra disebutkan seorang anak sudah boleh menikmati hubungan dengan lawan jenis. Kakawin Nittiśastra tampaknya tidak membatasi hak anak, Namun mengingatkan bahwa masa muda dan nafsu birahi dapat memengaruhi kesuksesan anak-anak dalam menempuh pengetahuan sehingga perlu dikendalikan.

Mendidik kepemimpinan dalam diri dan mendidik Anak dalam kakawin teks Kakawin Nitiśāstra dijelaskan ada enam musuh yang patut diwaspadai bahkan dijauhi ketika sedang menempuh pengetahuan, yaitu malas, suka berdusta, sakit menahun, masa muda penuh nafsu asmara, suka bermain wanita, dan suka berjudi. Keenam musuh tersebut dijelaskan pada kutipan berikut.

Satata musuh ning mangarěki widyā, sad-ika wilangnyengètakèna denta, ulah-ing-alěswa mala nika magöng,

Terjemahan: apituwi sang wyāsana ya ri dusta.

Yang senantiasa menjadi musuh bagi orang yang sedang belajar pengetahuan. Ada enam jenis yang patut diingat olehmu. Prilaku malas yang berdampak sangat besar. Begitu pula kebiasaan berbuat dusta.

Nguni-nguni yan wwang gěring-ati ruksa, pituwi sédhěng rāga taruna manwam, kimuta yadin wwang satata daridra, lawan-ing-ulah dyah ta sahanitādi.

Terjemahan:

Terlebih lagi orang yang sakit menahun. Begitu pula masa-masa sedang remaja yang penuh dengan nafsu asmara. Apalagi jika seseorang memang doyan perempuan. Serta ulah suka berjudi dan sejenisnya.

Suarka (2016) menjelaskan teks Kakawin Nitiśästra tidak membatasi hak anak dalam memenuhi kebutuhan biologisnya. Teks Kakawin Nitiśāstra mengakui bahwa pada usia dua puluh tahun, anak-anak tumbuh menjadi remaja dewasa dengan perkembangan karakteristik seksual. Pada fase tersebut, anak-anak pantas diberikan atau dijamin hak-haknya di bidang seksual (smara wisaya rwang puluh ing ayusya; apan ikanang yowana wisayābwat). Namun demikian, teks Kakawin Nitiśāstra juga mengingatkan bahwa masa muda dan nafsu asmara dapat memengaruhi kesuksesan anak-anak.

Jika ditelisik lebih mendalam ajaran-ajaran dalam Kakawin Nitiśāstra berkolerasi sangat erat dengan asta brata. Astabrata sebagai delapan sifat mulia para dewa (Ișța Dewata) dalam pandangan Hindu sebagai pelayanan kepada masyarakat, dan integritas untuk diri sendiri dalam melakukan Sevaka Dharma. Manava Seva Madhava Seva yang artinya melayani sesama mausia sama dengan melayani Tuhan. Maka konsep ajaran tersebut sangat berkaitan dengan Kakawin Nitiśāstra. Kedelapan kepemimpinan astabrata sebagaimana dijelaskan dalam Kakawin Ramayana, sebagai berikut.

1. Indra Brata, yakni mengikuti laksana Dewa Indra dianggap mengadakan hujan di dunia caranya dengan memberi atau menurunkan hujan kepada bumi sama rata, tidak boleh pilih kasih. Artinya, seorang pemimpin harus mampu memberi kesenangan, 
mengayomi, dan memberi kesejahteraan pada bawahan atau orang-orang yang dipimpin.

2. Yama Brata, yakni mengikuti laksana Dewa Yama dianggap menjadi dewa yang mengatur, dan menghukum orang yang berbuat curang dan memuji orang suci, jujur, dan setia. Artinya, seorang pemimpin harus mampu berlaku adil dan tegas, menghukum atau memberi sanksi kepada yang salah dan memberi penghargaan pada yang berprestasi.

3. Surya Brata, yakni mengikuti laksana Dewa Surya adalah tiap-tiap hari memanasi atau menerangi seluruh alam karena panasnya seluruh isi dan penghuni alam ini dapat bergerak atau tumbuh dengan baik. Oleh karena terangnya mereka dapat berjalan dengan cepat tidak meraba-raba dalam kegelapan. Artinya, seorang pemimpin harus mampu memberikan penerangan dan kekuatan pada orang-orang yang dipimpin.

4. Chandra Brata, yakni mengikuti laksana Dewa Candra yang tercermin dalam sifat-sifat bulan, tatkala bulan penuh (purnama) semua penghuni dunia senang olehnya. Kias rakyat bahwa alam semesta ramah-tamah dan menunjukkan muka yang tenang kepada rakyat atau pengikutnya, baik dalam keadaan senang maupun kesu-sahan. Artinya, seorang pemimpin harus dapat memberi kesejukan dan kenyamanan pada bawahannya.

5. Bayu Brata, yakni mengikuti laksaa Dewa Bayu, sifat bayu (angin) ini tersebar keseluruh pelosok penjuru dunia sampai kepada badan seluruh makhluk untuk memberi kesejateraan hidupnya dengan tak dapat dilihat orang. Artinya, seorang pemimpin harus memahami hal ikhwyal orang-orang yang dipimpin.

6. Kuwera Brata, yakni mengikuti laksana Dewa Kuwara dianggap dewa kekayaan. Pemimpin harus mengikhtiarkan kekayaan harta benda untuk kemegahan dan kemakmurannya dan seorang pemimpin harus berpenampilan simpatik dan rapi, baik dala penampilan maupun dalam bertutur kata.

7. Waruna Brata, yakni mengikuti laksana Dewa Baruna dianggap dewa yang bersenjatakan Naga Panca yang bertugas membasmi sekalian durjana dan musuh. Artinya, pemimpin harus memiliki penge $\neg$ tahuan atau wawasan yang luas sehingga mampu mengendalikan" bawahannya dengan kearifan dan kebijaksanaan.

8. Agni Brata, yakni mengikuti laksana Dewa Agni, sifatnya agni (api) yang selalu menyala dan berkobar. Artinya, seorang pemimpin hendaknya mampu memberikan semangat, motivasi dan harapan dalam kehidupan masyarakat.

Asta Brata dalam kakawin Ramāyana yang merupakan kakawin mayor sangat berkaitan dengan kakawin Nītiśātra, namun yang paling terpenting ajaran kakawin Nītiśāstra terformulasi dengan jelas pada kutipan kakawin Ramayana I.3.

\section{"Gunamanta sang Dasaratha \\ Wruh sira ring Weda, Bhakti Ring Dewa \\ Tar Malupeng Pitra Puja \\ Masih ta Sireng Swagotra kabeh"}

Terjemahan:

Gunawanlah Sang Dasarata, mengetahui beliau akan isi Weda, bhakti pada para Dewa (Ida Sang Hyang Widhi Wasa), tidak lupa pada pemujaan pada leluhur, beliau juga sangat menyayangi keluarganya.

Sang Dasaratha adalah salah satu contoh orang dalam karya sastra karena mampu memimpin diri sendiri, keluarga dan memimpin masyarakat. Melalui pemahaman akan ajaran Veda dan penerapannya, berbhakti kepada Tuhan dan melakukan pemujaan kepada leluhur. Itulah pemimpin yang paripurna menurut Hindu. Kepemimpinan dalam teks Hindu seperti 
kakawin Nìtiśāstra, kakawin Ramāyana, dll, senantiasa berorientasi kepada tujuan hidup sekala dan niskala, jagatditha dan moksa yaitu, terpeliharanya keseimbangan hidup lahir dan batin. Ajaran kepemimpinan Asta Brata merupakan pegangan bagi seorang pemimpin, sedangkan konsep Catur Upaya Sandhi merupakan landasan operasionalnya. Inilah yang disebut sebagai pengetahuan kehidupan (gelar urip) dan pengetahuan spiritual (gelar paraning dumadi).

\section{KESIMPULAN}

Kakawin adalah salah satu karya sastra Jawa Kuno yang mengandung nilai humanis sangat tinggi. Nilai-nilai yang dikandungnya dapat membentuk karakter positif setiap penbacanya. Sebagai suatu karya sastra, kakawin memiliki nilai estetika yang terlahir dari gaya bahasa yang digunakan dalam penggubahannya. Keindahan bahasa yang digunakan dalam kakawin lebih dikenal dengan istilah alamkara. Kakawin Nìtiśāstra hanya berisikan dan memuat anuprasa serta sabdālamkara yaitu puspayamaka dan wrêtantayamaka, namun didalam Kakawin Nìtiśāstra tidak ditemukannya sabdālaṃkara yang lain seperti kanciyamaka, padādyantayamaka, padantayamaka. Astabrata sebagai delapan sifat mulia para dewa (Ișta Dewata) dalam pandangan Hindu sebagai pelayanan kepada masyarakat, dan integritas untuk diri sendiri dalam melakukan Sevaka Dharma. Manava Seva Madhava Seva yang artinya melayani sesama mausia sama dengan melayani Tuhan. Maka konsep ajaran tersebut sangat berkaitan dengan Kakawin Nitiśästra. Kepemimpinan dalam teks Hindu seperti kakawin Nìtiśāstra senantiasa berorientasi kepada tujuan hidup sekala dan niskala, jagatditha dan moksa yaitu, terpeliharanya keseimbangan hidup lahir dan batin.

\section{Daftar Pustaka}

Anandakusuma, S.R. 1986. Kamus Bahasa Bali: Bali-Indonesia dan Indonesia-Bali. C.V. Kayumas. 374 p.

Budha Gautama, Wayan. 2009. kakawin Nìtiśāstra. Gianyar: Pesantian Widya Waúitta Petak Kaja Gianyar.

Hooykaas, C.1958a. "Four-Line Yamaka In The Old Javanese Ramayana", JRAS 58(71),pp.122-138.

Pudja, Gde dan Tjokorda Rai Sudharta. 1995. Manawa Dharmasastra (Manu Dharma Sastra). Jakarta: Hanuman Sakti.

R. Ng. Poerbatjaraka. 1932. Niti-Çastra. Bandoeng:Nix.

Suarka, I Nyoman, A.A. Gede Bawa, Komang Paramartha. 2016. Citra dan Hak Anak Menurut Kakawin Nitiśāstra. Jurnal Kajian Bali Vol. 06, No. 02, Oktober 2016. Denpasar: Universitas Udayana

Suarka, I Nyoman. 2012. Telaas Sastra Kakawin Sebuah Pengantar cet. II.Denpasar:Pustaka Larasan

Tim. 2001. Kakawin Ramayana I. Denpasar: Departemen Agama RI dan Kanwil Departemen Agama Provinsi Bali.

Tim. 2001. Kakawin Ramayana II. Denpasar: Departemen Agama RI dan Kanwil Departemen Agama Provinsi Bali.

Zoetmulder, P.J. 1985. Kalangwan Sastra Jawa Kuna Selayang Pandang Cet II. Jakarta:Djambatan

Zoetmulder, P.J. dan S.O. Robson. 2011. Kamus Bahasa Jawa Kuno-Indonesia Cet.VI

(Diterjemahkan oleh Danusuprapta dan Sumarti Suprayitna). Jakarta:Gramedia Pustaka Utama 